\title{
CENTRE OF RESEARCH AND RESTORATION OF THE MUSEUMS OF FRANCE: AMS RADIOCARBON DATES LIST 1
}

\author{
P Richardin ${ }^{1,2} \cdot \mathrm{N}_{\text {Gandolfo }}{ }^{1} \cdot \mathrm{B}_{\text {Moignard }}{ }^{1} \cdot \mathrm{C}_{\text {Lavier }^{1}} \bullet \mathrm{C}$ Moreau $^{3} \bullet$ E Cottereau $^{4}$
}

ABSTRACT. The national project for the measurement of radiocarbon includes different scientific partners for the accelerator named ARTEMIS (French acronym for Accélérateur pour la Recherche en sciences de la Terre, Environnement, Muséologie Installé à Saclay), available to the scientific community since 2004 (Cottereau et al. 2007). The French Ministry of Culture uses this accelerator mass spectrometry (AMS) facility at the request of archaeologists or curators of museums or of historical monuments. For the preparation of some samples, a laboratory has been installed at the Centre of Research and Restoration of the Museums of France, located in the Louvre Palace. In this report, the first data carried out on vegetal samples from museum objects or archaeological remains, dates are presented in terms of yr BP (before AD 1950).

\section{SAMPLE PREPARATION}

\section{Pretreatment}

The method used for vegetal samples (wood, charcoal, cotton, etc.) is based on a classical method. In order to eliminate all insoluble impurities (e.g. dust, sediments, and textile fibers due to the manipulation of museum objects), samples are first washed in an ultrasonic bath with ultrapure water. They then undergo the classical acid-alkali-acid (AAA) procedure. First, they are treated with a $0.5 \mathrm{M}$ hydrochloric acid $\mathrm{HCl}$ solution (VWR International, used as received) for $1 \mathrm{hr}$ at $80{ }^{\circ} \mathrm{C}$. After removing the supernatant with a glass pipette, the remaining fragments are rinsed with warm water until neutral. A similar treatment is achieved with an aqueous solution of $0.05 \mathrm{~N} \mathrm{NaOH}$ (prepared from a sodium hydroxide solution at $0.1 \mathrm{~N}$ from VWR International), followed by a rinse with ultrapure water. Another acidic treatment (similar to the first one) is done to remove all the carboxylic carbon formed during the alkali treatment. Finally, the clean samples are dried overnight in a low-vacuum ( $100 \mathrm{mbar}$ ) oven at $60^{\circ} \mathrm{C}$.

\section{Combustion and Graphitization}

The organic fraction has been then combusted at high temperature $\left(5 \mathrm{hr}\right.$ at $\left.850{ }^{\circ} \mathrm{C}\right)$ under high vacuum (at $10^{-6}$ Torr) on a semiautomatic combustion bench, whose principle is based on those of the LSCE radiocarbon laboratory (Hatté et al. 2003). A portion of the processed samples (2-2.5 mg) is combusted in a quartz tube with $500 \mathrm{mg} \mathrm{CuO}(\mathrm{Cu}(\mathrm{II})$ oxide on $\mathrm{Cu}(\mathrm{I})$ oxide heart for analysis, VWR International) and a piece of silver wire (99.95\%, Aldrich). The combustion gases $\left(\mathrm{H}_{2} \mathrm{O}\right.$ and $\mathrm{CO}_{2}$ ) are separated by cryogenic purification and the $\mathrm{CO}_{2}$ is collected in a sealed tube. The graphitization (Cottereau et al. 2007) of the obtained $\mathrm{CO}_{2}$ is achieved by direct catalytic reduction with hydrogen, using Fe powder (average particle size $10 \mathrm{~m}$ ) as catalyst at $600{ }^{\circ} \mathrm{C}$ and with an excess of $\mathrm{H}_{2}\left(\mathrm{H}_{2} / \mathrm{CO}_{2}=3\right)$. During this process, the carbon is deposited on the iron and the powder is mechanically pressed into a flat pellet.

\footnotetext{
${ }^{1}$ Laboratory of Centre of Research and Restoration of the Museums of France, LC2RMF - CNRS UMR 171, Palais du Louvre, 14 quai François Mitterrand, 75001 Paris, France.

${ }^{2}$ Corresponding author. Email: pascale.richardin@culture.gouv.fr.

${ }^{3}$ Laboratory for radiocarbon measurement, LMC14 - CNRS UMS 2572, bat 450, CEA Saclay, 91191 Gif-sur-Yvette Cedex, France.

${ }^{4}$ Laboratory for radiocarbon measurement, LMC14 - CNRS UMS 2572, bat 450, CEA Saclay, 91191 Gif-sur-Yvette Cedex, France. Present address: IN2P3, Institute of Nuclear Physic, bat 109, 91406 Orsay Cedex, France.
} 


\section{Measurements}

All measurements have been achieved at the AMS facility of Saclay (France). The radiocarbon activity is calculated by comparing the measured intensities of the ${ }^{14} \mathrm{C},{ }^{13} \mathrm{C}$, and ${ }^{12} \mathrm{C}$ beams from each sample with those of $\mathrm{CO}_{2}$ standards, prepared with $\mathrm{HOx}$ (I) oxalic acid reference, in pMC (percent modern carbon) normalized with a $\delta^{13} \mathrm{C}$ at $-25 \%$. The ${ }^{14} \mathrm{C}$ ages are calculated (Mook and van der Plicht 1999) by correcting the isotope fractionation $\delta^{13} \mathrm{C}$, measured by AMS with the ${ }^{13} \mathrm{C} /{ }^{12} \mathrm{C}$ ratio.

\section{MUSEUM ARTIFACTS}

Tupinamba Club, Inventory $N^{\circ}$ 71.1917.3.62, Quai Branly Museum, Paris, France (Métraux 1932; Richardin et al. 2007a; Delpuech 2009; Lavier et al. 2009)

This club, made from a very hard wood by the ethnic group Tupinamba (Brazil), was collected by André Thevet (1515-1590), cosmographer of King Henri II and François I. This weapon (iwera pemme) was used to ritually kill the war prisoners and was the object of particular attention before the execution of the captive who was then eaten. It dated from the 16th century, and thus is considered among the oldest pieces from the Americas in French museum collections.

\section{SacA 8310}

Wood samples from the decoration.

SacA 8311

Cotton samples from the decoration.

SacA 8312

Cotton samples from the decoration.

$$
450 \pm 50 \text { yr BP }
$$

$$
320 \pm 50 \text { yr BP }
$$

Chinese Manuscripts, Pelliot 2490 and 2547, National Library of France (BnF), Paris, France (Cuisance 2009; Richardin et al. 2010)

The 2 manuscripts come from the Library Cave at the Mogao near Dunhuang. They form a part of the collection acquired by the Sinologist and archaeologist Paul Pelliot (1878-1945) during his expedition in China and Central Asia from 1906 to 1908. These manuscripts were entrusted to the National Library of France in 1910. Pelliot 2490 dates to AD 952 and it is assumed that Pelliot 2547 was completed between AD 728 and 744.

\section{SacA 8716}

$1120 \pm 30$ yr BP

Wood fragments from the stick (2490).

SacA 8718

$1275 \pm 30$ yr BP

Wood fragments from the stick (2547).

SacA 8719

$1270 \pm 30$ yr BP

Wood fragments from the stick (2547) (this is a repetition of the previous sample SacA 8718 in order to confirm the result).

Bronze Lion Statue, Inventory $N^{\circ}$ YM36526, Sanaa Museum, Sanaa, Yemen (Demange et al. 2009; Richardin et al. 2009a)

Numerous charcoal fragments are inserted in the heart of this bronze statue, preserved by the National Sanaa Museum (Yemen). The restoration work was carried out at the C2RMF, Paris, France, under a cooperation agreement between the Yemeni General Organization for Antiquities 
and Museums (GOAM) and the French Museum of Louvre. This statue would have been discovered during illegal excavations in the region of Wadi Harib, but it could come from Tanna (Arbach 2005). It appears to derive from the third quarter of the 1 st century $\mathrm{BC}$, according to the inscription.

SacA 14487

Charcoal Y1A.

SacA 14488

CharcolY1B (this is a repetition of he previus sample SacA 14487 in order to c0nfinn 1 .

SacA 14489

Charcoal Y2.

SacA 14490

Charcoal Y3.

SacA 14502

Charcoal Y4.

SacA 14503

Charcoal M.1.

Sculptured Posts from the Site of Pachacamac (Peru), Quai Branly Museum, Paris, France (Moutarde 2006; Richardin and Lavier 2008)

These 5 sculptured posts were brought by Captain Paul Berthon in 1910, who bought them as idols, excavated from the cemetery of Pachacamac. Their originality was questioned during their entrance to the collections of the Museum of the Man, in Paris. If they are authentic pieces, they dated to the Middle Horizon (AD 500-1000). They are now in display in the Quai Branly Museum in the Americas collection.

\section{SacA 11061}

Wood fragments from the post, Inventory $\mathrm{N}^{\circ} 71.1911 .21 .502$.

\section{SacA 11062}

Wood fragments from the post, Inventory $\mathrm{N}^{\circ} 71.1911 .21 .502$ (this is a repetition of the previous sample SacA 11061 in order to confirm the result).

\section{SacA 11063}

Wood fragments from the post, Inventory $\mathrm{N}^{\circ}$ 71.1911.21.503.

SacA 11064

$$
940 \pm 30 \text { yr BP }
$$

$935 \pm 30$ yr BP

Wood fragments from the post, Inventory $\mathrm{N}^{\circ} 71.1911 .21 .503$ (this is a repetition of the previous sample SacA 11063 in order to confirm the result).

SacA 11120

$965 \pm 30$ yr BP

Wood fragments from the post, Inventory $\mathrm{N}^{\circ} 71.1911 .21 .504$.

SacA 11121

$895 \pm 30$ yr BP

Wood fragments from the post, Inventory $\mathrm{N}^{\circ} 71.1911 .21 .504$ (this is a repetition of the previous sample SacA 11120 in order to confirm the result).

SacA 11122

Wood fragments from the post, Inventory $\mathrm{N}^{\circ}$ 71.1911.21.505. 
SacA 11123

$945 \pm 30$ yr BP

Wood fragments from the post, Inventory $\mathrm{N}^{\circ} 71.1911 .21 .505$ (this is a repetition of the previous sample SacA 11122 in order to confirm the result).

\section{SacA 11125}

$910 \pm 30$ yr BP

Wood fragments from the post, Inventory $\mathrm{N}^{\circ} 71.1911 .21 .506$.

SacA 11126

$995 \pm 30$ yr BP

Wood fragments from the post, Inventory $\mathrm{N}^{\circ} 71.1911 .21 .506$ (this is a repetition of the previous sample SacA 11125 in order to confirm the result).

Funeral Masks from the Site of Pachacamac (Peru), Museum of Quai Branly, Paris, France (Richardin and Lavier 2008; Arriola 2009)

These 2 wooden masks were used as a part of the funeral fardos (funeral bags) and are displayed in the Quai Branly Museum in the Americas collection. They are estimated to date from the 6th to the 11 th century AD.

SacA 11057

$630 \pm 30$ yr BP

Wood fragments from the mask, old Ychsma culture, Inventory No71.1928.20.25@1.

SacA 11058

$1065 \pm 35$ yr BP

Wood fragments from the mask, Wari culture, Inventory $\mathrm{N}^{\circ} 71.1933 .90 .96$.

Medieval Wooden Statue, Inventory $\mathbf{N}^{\circ}$ 2006.3.1, Fenaille Museum, Rodez, France (Richardin et al. 2009b)

The Fenaille Museum of Rodez (Aveyron, France) recently has purchased a polychrome Roman wooden sculpture, which represents a Virgin in Majesty. The date of its fabrication is estimated between the 12th and the 13th century AD.

SacA 14051

$810 \pm 30$ yr BP

Wood fragment.

SacA 14052

$860 \pm 30$ yr BP

Wood fragment (this is a repetition of the previous sample SacA 14051 in order to confirm the result).

Medieval Wooden Statue, Inventory $\mathbf{N}^{\circ}$ 87.2.170, Crozatier Museum, Puy-en-Velay, France (Richardin et al. 2009c)

This wooden sculpture, "Virgin and Christ Child," from the Crozatier Museum, is thought to dated around the 12th century. The problem is whether the Virgin and the Child are contemporary or not.

\section{SacA 14046}

$735 \pm 30$ yr BP

Wood fragment from the Child.

SacA 14047

$725 \pm 30$ yr BP

Wood fragment from the Child (this is a repetition of the previous sample SacA 14046 in order to confirm the result).

SacA 14049

$220 \pm 30$ yr BP

Wood fragment from the Virgin. 
SacA 14050

$175 \pm 30$ yr BP

Wood fragment from the Virgin (this is a repetition of the previous sample SacA 14049 in order to confirm the result).

\section{Medieval Wooden Statues, Lorraine Museum, Nancy, France (Richardin et al. 2009d)}

This collection of Roman statues is one of the most important in the French museums and dates from the 12th to 13th century AD.

SacA 14031

Wood fragments from the statue, Inventory $\mathrm{N}^{\circ} \mathrm{C} 76.1$.

$$
845 \pm 30 \text { yr BP }
$$

SacA 14032

$905 \pm 30$ yr BP

Wood fragments from the statue, Inventory $\mathrm{N}^{\circ} \mathrm{C} 76.1$ (this is a repetition of the previous sample SacA 14031 in order to confirm the result).

SacA 14495

$1020 \pm 30$ yr BP

Wood fragments from the statue, Inventory $\mathrm{N}^{\circ} \mathrm{C} 76.1$ (this is a repetition of the other sample from the statue in order to confirm the result).

SacA 14029

$900 \pm 30$ yr BP

Wood fragments from the statue, Inventory $\mathrm{N}^{\circ} \mathrm{C} 105.1$.

SacA 14030

$965 \pm 30$ yr BP

Wood fragments from the statue, Inventory $\mathrm{N}^{\circ} \mathrm{C} 105.1$ (this is a repetition of the previous sample SacA 14029 in order to confirm the result).

SacA 14494

$955 \pm 30$ yr BP

Wood fragments from the statue, Inventory $\mathrm{N}^{\circ} \mathrm{C} 105.1$ (this is a repetition of the other sample from the statue in order to confirm the result).

\section{SacA 14037}

$340 \pm 30$ yr BP

Wood fragments from the statue, Inventory $N^{\circ}$ M.8.6.

SacA 14497

$455 \pm 30$ yr BP

Wood fragments from the statue, Inventory $\mathrm{N}^{\circ}$ M.8.6 (this is a repetition of the previous sample SacA 14037 in order to confirm the result).

SacA 14034

$1140 \pm 30$ yr BP

Wood fragments from the statue, Inventory $\mathrm{N}^{\circ}$ M.8.23.

SacA 14035

$1135 \pm 30$ yr BP

Wood fragments from the statue, Inventory $\mathrm{N}^{\circ}$ M.8.23 (this is a repetition of the previous sample SacA 14034 in order to confirm the result).

SacA 14039

$420 \pm 30$ yr BP

Wood fragments from the statue, Inventory $\mathrm{N}^{\circ}$ M.13.1.

SacA 14498

$445 \pm 30$ yr BP

Wood fragments from the statue, Inventory $\mathrm{N}^{\circ}$ M.13.1 (this is a repetition of the previous sample SacA 14039 in order to confirm the result).

SacA 13756

$715 \pm 30$ yr BP

Wood fragments from the Child, Inventory $\mathrm{N}^{\circ} \mathrm{M} .13 .2$. 
SacA 13757

$730 \pm 30$ yr BP

Wood fragments from the Child, Inventory $\mathrm{N}^{\circ}$ M.13.2 (this is a repetition of the previous sample SacA 13756 in order to confirm the result).

SacA 14493

$740 \pm 30$ yr BP

Wood fragments from the Child, Inventory $\mathrm{N}^{\circ}$ M.13.2 (this is a repetition of the other sample from the statue in order to confirm the result).

SacA 14045

$280 \pm 30$ yr BP

Wood fragments from the Virgin, Inventory $\mathrm{N}^{\circ}$ M.13.2.

SacA 14500

$330 \pm 30$ yr BP

Wood fragments from the Virgin, Inventory $\mathrm{N}^{\circ}$ M.13.2 (this is a repetition of the previous sample SacA 14045 in order to confirm the result).

SacA 13754

$290 \pm 30$ yr BP

Wood fragments from the statue, Inventory $\mathrm{N}^{\circ}$ M.13.3.

SacA 13755

$320 \pm 30$ yr BP

Wood fragments from the statue, Inventory $\mathrm{N}^{\circ}$ M.13.3 (this is a repetition of the previous sample SacA 13754 in order to confirm the result).

SacA 14492

$250 \pm 30$ yr BP

Wood fragments from the statue, Inventory $\mathrm{N}^{\circ}$ M.13.3 (this is a repetition of the other sample from the statue in order to confirm the result).

SacA 14026

$795 \pm 30$ yr BP

Wood fragments from the statue, Inventory $\mathrm{N}^{\circ}$ M.13.4.

SacA 14027

$830 \pm 30$ yr BP

Wood fragments from the statue, Inventory $\mathrm{N}^{\circ}$ M.13.4 (this is a repetition of the previous sample SacA 14026 in order to confirm the result).

SacA 14041

$615 \pm 30$ yr BP

Wood fragments from the statue, Inventory $\mathrm{N}^{\circ}$ M.13.5.

SacA 14499

$745 \pm 30$ yr BP

Wood fragments from the statue, Inventory $\mathrm{N}^{\circ}$ M.13.5 (this is a repetition of the previous sample SacA 14041 in order to confirm the result).

SacA 14024

Wood fragments from the statue, Inventory $\mathrm{N}^{\circ}$ 2007.0.2053.

$190 \pm 30$ yr BP

SacA 14025

$275 \pm 30$ yr BP

Wood fragments from the statue, Inventory $\mathrm{N}^{\circ}$ 2007.0.2053 (this is a repetition of the previous sample SacA 14024 in order to confirm the result).

Three Wooden Fragments from Sarcophagus A9 of the Basilica of Saint-Denis and Preserved by the Museum of National Archaeology, Saint-Germain-en-Laye, France (Fleury and FranceLanord 1998; Richardin and Gandolfo 2009a,b)

These 3 fragments of boards from the Merovingian sarcophagus A9 of the Basilica of Saint-Denis have been dated to confirm and refine the results from the dendrochronology and also to confirm the archaeological hypotheses (the date is estimated at the second half of the 6th century). 
SacA 13565

$1640 \pm 30$ yr BP

Wood fragment, Inventory P1.

$1590 \pm 30$ yr BP

SacA 13566

Wood fragment, Inventory P1 (this is a repetition of the previous sample SacA 13565 in order to con-
firm the result). firm the result).

SacA 13567

$1640 \pm 30$ yr BP

Wood fragment, Inventory P2.

SacA 13568

$1645 \pm 30$ yr BP

Wood fragment, Inventory P2 (this is a repetition of the previous sample SacA 13567 in order to confirm the result).

SacA 13751

$1685 \pm 30$ yr BP

Wood fragment, Inventory P3.

SacA 13752

$1680 \pm 30$ yr BP

Wood fragment, Inventory P3 (this is a repetition of the previous sample SacA 13751 in order to confirm the result).

\section{ARCHAEOLOGICAL SAMPLES}

Charcoal Samples from the Archaeological Site of Petit Paulmy at Abilly, Indre-et-Loire, France, Archeolab Museum, France (Richardin et al. 2008; Richardin and Gandolfo 2009b; Marguerie and Gaudin 2011)

These small charcoal fragments have been collected on the site of Petit Paulmy, France $\left(46^{\circ} 56^{\prime} 31^{\prime \prime} \mathrm{N}, 43^{\circ} 43^{\prime} \mathrm{E}\right)$ and date from the Final Neolithic (between 3000 and $2000 \mathrm{BC}$ ).

SacA 14055

$2670 \pm 30$ yr BP

Charcoal fragments, Inventory $\mathrm{N}^{\circ} \mathrm{J} 0021 \mathrm{c.IIa}(\mathrm{z}=240-235)$.

SacA 14057

$4110 \pm 30$ yr BP

Charcoal fragments, Inventory $\mathrm{N}^{\circ} \mathrm{K} 0096 / 2 \mathrm{c}$ c.IIa $(\mathrm{z}=250-245)$.

SacA 14058

$4080 \pm 35$ yr BP

Charcoal fragments, Inventory $\mathrm{N}^{\circ} \mathrm{K} 0096 / 3$ c.IIa ( $\left.\mathrm{z}=250-245\right)$.

SacA 14060

$1790 \pm 80$ yr BP

Charcoal fragments, Inventory $\mathrm{N}^{\circ} \mathrm{K} 0095$ c.IIa ( $\left.\mathrm{z}=245-240\right)$.

SacA 14061

$2725 \pm 30$ yr BP

Charcoal fragments, Inventory $\mathrm{N}^{\circ} \mathrm{J} 8095 / 4$ C.IIa $(\mathrm{z}=245-240)$.

SacA 14063

$495 \pm 30$ yr BP

Charcoal fragments, Inventory $\mathrm{N}^{\circ} \mathrm{J} 6081 \mathrm{c.IIa}(\mathrm{z}=240-235)$.

SacA 15018

$2555 \pm 30$ yr BP

Charcoal fragments, Inventory $\mathrm{N}^{\circ} \mathrm{K} 0096 / 4$ c.IIa ( $\left.\mathrm{z}=250-245\right)$.

SacA 10604

$4140 \pm 30$ yr BP

Charcoal fragments, Inventory $\mathrm{N}^{\circ} \mathrm{K} 0096 / 1$ c.IIa $(\mathrm{z}=240-235)$. 
SacA 10605

$4125 \pm 30$ yr BP

Charcoal fragments, Inventory $\mathrm{N}^{\circ} \mathrm{K} 0096 / 1 \mathrm{c}$.IIa $(\mathrm{z}=240-235)$ (this is a repetition of the previous sample SacA 10604 in order to confirm the result).

SacA 10607

$4005 \pm 35$ yr BP

Charcoal fragments, Inventory $\mathrm{N}^{\circ} \mathrm{J} 8095 / 4$ c.IIa $(\mathrm{z}=245-240)$.

SacA 10608

$3950 \pm 30$ yr BP

Charcoal fragments, Inventory $\mathrm{N}^{\circ} \mathrm{J} 8095 / 4$ c.IIa $(\mathrm{z}=245-240)$ (this is a repetition of the previous sample SacA 10607 in order to confirm the result).

Charcoal Samples, Tetiaroa, Tahiti, France (Emory 1933; Vérin 1962; Sinoto and McCoy 1974; Richardin et al. 2009e)

Tetiaroa atoll $\left(17^{\circ} 05^{\prime} \mathrm{S}, 149^{\circ} 30^{\prime} \mathrm{W}\right)$ lies $50 \mathrm{~km}$ north of Moorea and Tahiti, in French Polynesia. The samples were collected by M Hardy under the stones of foundation of Marae (a square which was reserved for the religious and social activities of the Polynesian community) and could be dated of the period of their construction and perhaps the period when the atoll was populated.

SacA 15014

$370 \pm 30$ yr BP

Charcoal fragments, Ref. No 8.6-S1-C3.

SacA 15015

Charcoal fragments, Ref. N 8.7-S8-C3.

SacA 15016

Charcoal fragments, Ref. No $8.6-\mathrm{S} 7-\mathrm{C} 4$.

SacA 15020

$485 \pm 30$ yr BP

Charcoal fragments, Ref. No 8.6-S7-C3.

$365 \pm 30$ yr BP

SacA 15021

$370 \pm 30$ yr BP

Charcoal fragments, Ref. $\mathrm{N}^{\circ}$ 8.6-S7-C3 (this is a repetition of the previous sample SacA 15020 in order to confirm the result).

Charcoal Samples, Asgoumhati, Djibouti (Poisblaud 2004-2005; Richardin et al. 2007b)

Two series of excavations allowed discovering an important site of the recent prehistory of Djibouti: Asgoumhati. This sample of charcoal has been found in 2004, under a flat stone of a funeral monument of this culture, which was partially destroyed. Unfortunately, this sample does not date the monument but an occupation near it.

SacA 8015

$395 \pm 20$ yr BP

Charcoal fragments, Ref. YC12.

SacA 8016

$410 \pm 25$ yr BP

Charcoal fragments, Ref. YC12 (this is a repetition of the previous sample SacA 8015 in order to confirm the result).

Charcoals, Goudours, Haute-Vienne, France (Richardin et al. 2007c; Joussaume et al. 2008)

These charcoals were collected from the dolmen of Goudours, so-called Cluzeau or Vergnes, located at Folles, Limousin, France. 
SacA 8040

$1615 \pm 30$ yr BP

Charcoal fragments, Ref. F7.

$1580 \pm 30$ yr BP

SacA 8041

Charcoal fragments, Ref. F7 (this is a repetition of the previous sample SacA 8040 in order to con-
firm the result). firm the result).

SacA 8042

$130 \pm 30$ yr BP

Charcoal fragments, Ref. G7 Passe IV.

SacA 8044

$400 \pm 30$ yr BP

Charcoal fragments, Ref. F6.3.

SacA 8045

Charcoal fragments, Ref. F6.4.

SacA 8046

Charcoal fragments, Ref. F6.7.

SacA 8047

$1485 \pm 30$ yr BP

Charcoal fragments, Ref. F6.17.

SacA 8309

$2070 \pm 30$ yr BP

Charcoal fragments, Ref. F6 dec I.

Charcoal, Tuto Fela, Ethiopia (Joussaume 2007; Richardin et al. 2007d)

A sample of charcoal was excavated in 1997 on the site of Tuto Fela in Ethiopia, by the team of Roger Joussaume, in charge of the archaeological mission. The sample was taken under the tumulus of anthropomorphic steles. The age is important, because it will allow knowing the end of the use of the site.

\section{SacA 8017}

$525 \pm 25$ yr BP

Charcoal fragments, Ref. F6.G6.

SacA 8018

$575 \pm 25$ yr BP

Charcoal fragments, Ref. F6.G6 (this is a repetition of the previous sample SacA 8017 in order to confirm the result).

Wicker and Wooden Ligatures Samples, Karadong Site, Xinjiang, Khotan Region, China (Debaine-Francfort 2001; Debaine-Francfort et al. 2001; Richardin et al. 2007e)

In the southern part of the Taklamakan Desert in China's Xinjiang Province, Karadong was the capital of the ancient delta of the Keriya River at the beginning of Christian era. Once a caravan stop, the site bears the remains of a farming community, with a small fort and half-timbered dwellings. The samples come from levels of housing environment: vegetable ligature inside a wall of house KRD 42F, made of poplar, tamarisk, reeds, alluvium, and sand.

SacA 8726

$1705 \pm 30$ yr BP

Wood fragments extracted from the ligature, Ref. KRD45a.

SacA 8727

$1695 \pm 30$ yr BP

Wood fragments extracted from the ligature, Ref. KRD45a (this is a repetition of the previous sample SacA 8726 in order to confirm the result). 
SacA 8728

$1590 \pm 30$ yr BP

Wicker fragments extracted from the ligature, Ref. KRD45b.

Wood Fragment of Coffin, Djoumboulak Koum Site, Xinjiang, Khotan Region, China (Richardin et al. 2007e)

In the Taklamakan Desert, Djoumboulak Koum (Yuansha gucheng in Chinese) was an oasis capital in the protohistoric delta of the Keriya River during the 1st millennium BC. The site itself is a complete ensemble: a fortified city in an irrigated environment, with its cemeteries outside its walls. It provides previously unknown information concerning settlement patterns of sedentary population in southern Xinjiang during the Iron Age. The samples were taken from a coffin, in Cemetery D.

SacA 8713

$2275 \pm 30$ yr BP

Wood fragment, Grave MD 13 (mummy), cemetery D, Ref. MD22.

$2255 \pm 30$ yr BP

SacA 8714 Wood fragment, Grave MD 13 (mummy), cemetery D, Ref. MD22 (this is a repetition of the previous sample SacA 8713 in order to confirm the result).

Protohistoric Sites Discovered during the Survey of the Keriya River, Xinjiang, Khotan Region, China (Richardin et al. 2007e)

The samples were taken in various places discovered by the Franco-Chinese Archaeological Mission along the fossil courses of the Keriya River protohistorical delta in the Taklamakan Desert. A survey of this delta has provided evidence of a totally unknown human habitation with a rich pastoral and agricultural history along the dried-up waterways through which the Keriya once coursed.

SacA 8711

$2205 \pm 35$ yr BP

Plant textile, braided cordon, site 71*, Ref. PROSP 37v.

SacA 8712

$2255 \pm 30$ yr BP

Plant textile, braided cordon, site $71^{*}$, Ref. PROSP $37 \mathrm{v}$ (this is a repetition of the previous sample SacA 8711 in order to confirm the result).

SacA 8714

$2235 \pm 30$ yr BP

Wood fragment from a coffin, site 73*, Ref. PROSP 38.

SacA 8315

$4020 \pm 35$ yr BP

Fragment of timber of a house, site 83*, Ref. PROSP 41.

SacA 8316

$2105 \pm 30$ yr BP

Charcoal, hearth, site $85^{*}$, Ref. PROSP 42.

SacA 8317

$2200 \pm 30$ yr BP

Charcoal from the inferior level (under M5), site Liushui*, Ref. PROSP 43.

\section{ACKNOWLEDGMENTS}

The authors are very grateful to Françoise Cuisance (conservator, in charge of the restoration of the BNF's Chinese Pelliot collection at the National Library of France, Paris), Corinne DebaineFrancfort (archaeologist, CNRS-UMR 7041, joint director of the Franco-Chinese Archaeological Mission in Xinjiang, China), Michèle Dejean (conservator, Quai Branly Museum, Paris), Thierry Delcourt (director of the Manuscripts Department, National Library of France, Paris), André Delpuech (curator, in charge of the Americas collections, Quai Branly Museum, Paris), Françoise 
Demange (curator, Oriental Antiquities Department, Louvre Museum, Paris), Gilles Grandjean (curator, Crozatier Museum, Puy-en-Velay, France), Maurice Hardy (archaeologist, CNRS-UMR 7041, in charge of the Tetiaroa's excavations, Tahiti, France), Roger Joussaume (archaeologist, Goudours site, France and Tuto Fela site, Ethiopia), Christine Lancestremère (curator, Museum of the French Monuments, Paris), Jean-Claude Marquet (archaeologist, in charge of the study of Petit Paulmy site and curator at the Archeolab Museum, Abilly, France), Eric Moinet (curator, Museum of Lorraine, Nancy, France), Paz Núñez-Regueiro (curator, Quai Branly Museum, Paris), Patrick Perin (curator and director of the National Museum of Archaeology, Saint-Germain-en-Laye, France), Aurélien Pierre (curator in charge of the collections, Fenaille Museum, Rodez, France), Benoit Poisblaud (archaeologist, CNRS-UMR 7041 and INRAP, site of Asgoumhati, Djibouti).

The authors thank Evelyne Kaltnecker and Jean-François Tannau (LSCE, CNRS-UMR 1572, Gifsur-Yvette, France) for their collaboration during the installation of the laboratory for sample preparation and for the construction of our combustion bench. We want to thank also all the students who have worked on the team since the beginning of laboratory installation: Stéphanie Couvreur, Julie Durieux, Maryline Langlois, Valentin Rottier, and Julien Sinquin for the sample preparation. Lastly, this paper has been written in the memory of Joseph Salomon (1955-2009), our colleague and friend, who was one of the pioneers of the National Project for the measurement of ${ }^{14} \mathrm{C}$ in France.

\section{REFERENCES}

Arbach M. 2005. Un lion en bronze avec un nouveau synchronisme minéo-qatabanite. In: Archaeological, Epigraphical and Historical Studies in Honour of $Y$. M. 'Abdallah, A. de Maigret and Ch. Robin on the Occasion of their 60th birthday. Sana'a-Naples: Sabean Studies. p 22.

Arriola LD. 2009. Masque funéraire. Pachacamac, Perou. In: Musée du quai Branly, La Collection, dir. Y. Le Fur. Paris: Skira Flammarion. p 362-4.

Cottereau E, Arnold M, Moreau C, Baqué D, Bavay D, Caffy I, Comby C, Dumoulin JP, Hain S, Perron M, Salomon J, Setti V. 2007. ARTEMIS, the new ${ }^{14} \mathrm{C}$ AMS at LMC14 in Saclay, France. Radiocarbon 49(2):291-9.

Cuisance F. 2009. Undoing old and doing new conservation on Pelliot Chinois 2547 and 2490. IDP News, Newsletter of the International Dunhuang Project (ISSN 1354-5914) Spring 2009. Volume 33. p 5-7.

Debaine-Francfort C. 2001. Les oasis retrouvées de Keriya. Archéologia 375:16-29.

Debaine-Francfort C, Idriss A. 2001. Keriya, mémoires d'un fleuve, Archéologie et civilisation des oasis du Taklamakan. Paris: éditions Findakly.

Delpuech A. 2009. Casse-tête. Brésil. Tupinamba. In: Musée du quai Branly, La Collection, dir. Y. Le Fur. Paris: Skira Flammarion. p 380-1.

Demange F, Arbach M, Mille B, Pariselle C, Rérolle C, Meyohas ME, Barret M. 2009. Lions du Yémen antique, brèves incursions dans la mémoire du Yémen. Paris: Musée du Louvre, Actualités du département des Antiquités Orientales 13.

Emory KP. 1933. Stone remains in the Society Islands. Bernice P Bishop Museum Bulletin 116. Honolulu: BP Bishop Museum. 204 p.
Fleury M, France-Lanord A. 1998. Les trésors mérovingiens de la basilique de Saint-Denis, eds. G. Koepp, 57 Woippy, France.

Hatté C, Poupeau JJ, Tannau JF, Paterne M. 2003. Development of an automated system for preparation of organic samples. Radiocarbon 45(3):421-30.

Joussaume R. 2007. Tuto Fela et les stèles du sud de l'Ethiopie. Saint-Just-la-pendue: Eds. Recherches sur les Civilisations.

Joussaume R, Crédot R, Giraud C, Bernard R, Cros J-P, Fouere P, Mens E. 2008. Le dolmen des Goudours à Folles (Haute-Vienne) et les dolmens à chambre axiale allongée dans le Centre-Ouest de la France. Préhistoire du Sud-Ouest 16:3-54.

Lavier C, Borel T, Vigears D. 2009. Traceology applied to wooden artefacts ans works of art in French national museums: initial examples of adaptations, technical developments and results at C2RMF. Technè 29:1520.

Marguerie D, Gaudin L. 2011. Le Petit-Paulmy (Abilly, Indre-et-Loire). Etude anthracologique et dendrologique. Rapport d'étude. In: Marquet J-C, MilletRichard L-A. Le Petit-Paulmy. Abilly (Indre-et-Loire). Un habitat du Néolithique final de la région pressignienne. Archaeolab Museum.

Métraux A. 1932. A propos de deux objets tupinamba. Bulletin du Musée d'Ethnographie du Trocadéro. p 318.

Mook WG, van der Plicht J. 1999. Reporting ${ }^{14} \mathrm{C}$ activities and concentrations. Radiocarbon 41(3):227-39.

Moutarde F. 2006. L'évolution du couvert ligneux et de son exploitation par l'homme dans la vallée du Lurin (côte centrale du Pérou), de l'Horizon Ancien (9001000 av. J.-C.) à l'Horizon Tardif (1460-1532 ap. J.- 
C.). Approche anthracologique [PhD dissertation]. University of Paris I. p 168-9.

Poisblaud B. 2004-2005. Recherche sur la Préhistoire récente en République de Djibouti. Le site d'Asgoumhati. Afrique: Archéologie et Arts 3:117-22.

Richardin P, Gandolfo N. 2009a. Datation par le carbone14 de trois fragments de bois provenant du sarcophage A9 de Saint-Denis (deuxième du VIe siècle) et conservés au Musée d'Archéologie. Internal report C2RMF-6231, unpublished results.

Richardin P, Gandolfo N. 2009b. Datation par le carbone14 de neuf charbons de bois de très petite taille provenant des fouilles du Petit Paulmy (Musée Archeolab). Internal report C2RMF-16117, unpublished results.

Richardin P, Lavier C. 2008. Datation par le carbone-14 de cinq poteaux de soutènement et de deux masques funéraires en bois provenant du site de Pachacamac (Pérou) et conservés au Musée du quai Branly. Internal report C2RMF-14420, unpublished results.

Richardin P, Durieux J, Salomon J. 2007a. Datation par le carbone-14 d'une massue en bois Tupinamba, Brésil (Musée du quai Branly) - $\mathrm{N}^{\circ}$ d'inventaire: 71.1917.3.62. Internal report C2RMF-8011, unpublished results.

Richardin P, Lavier C, Fossey A, Salomon J. 2007b. Datation par le carbone-14 d'un charbon de bois issu des fouilles du site d'Asgoumhati (Djibouti). Internal report C2RMF-11691, unpublished results.

Richardin P, Lavier C, Fossey A, Salomon J. 2007c. Datation par le carbone-14 de quatre charbons de bois issus des fouilles du Dolmen de Goudours à Folles (Haute-Vienne). Internal report C2RMF-11693, unpublished results.

Richardin P, Lavier C, Fossey A, Salomon J. 2007d. Datation par le carbone-14 d'un charbon de bois issu des fouilles de Tuto Fela (Ethiopie). Internal report C2RMF-11694, unpublished results.

Richardin P, Durieux J, Fossey A, Couvreur S, Salomon J. 2007e. Datation par le carbone-14 d'échantillons d'origine végétale issus des fouilles des sites de Karadong, Djoumboulak Koum et quelques sites en prospection (Chine). Internal report C2RMF-11694, unpublished results.

Richardin P, Lavier C, Langlois M. 2008. Datation par le carbone-14 de deux charbons de bois provenant des fouilles du Petit Paulmy (Musée Archeolab). Internal report C2RMF-14471, unpublished results.

Richardin P, Gandolfo N, Sinquin J. 2009a. Datation par le carbone-14 de sept fragments de charbon de bois issus du sédiment de remplissage d'une sculpture en bronze provenant du musée de Sanaa (Yémen). Internal report C2RMF-16878, unpublished results.

Richardin P, Gandolfo N, Lavier C. 2009b. Datation par le carbone-14 d'une sculpture médiévale conservée au Musée Fenaille (Rodez, Aveyron, Midi-Pyrénées). Internal report C2RMF-16504, unpublished results.

Richardin P, Gandolfo N, Lavier C. 2009c. Datation par le carbone-14 d'une sculpture médiévale en bois provenant du musée Crozatier (Puy-en-Velay, HauteLoire, Auvergne). Internal report C2RMF-6503, unpublished results.

Richardin P, Gandolfo N, Lavier C. 2009d. Datation par le carbone-14 d'une série de dix statues religieuses romanes conservées au Musée Lorrain (Nancy). Internal report C2RMF-16388, unpublished results.

Richardin P, Gandolfo N, Rottier V. 2009e. Datation par le carbone-14 de quatre échantillons de charbon de bois provenant des fouilles de Tetiaroa et conservés au Service Archéologique de Tahiti. Internal report C2RMF-17225, unpublished results.

Richardin P, Cuisance F, Buisson N, Asensi-Amoros V, Lavier C. 2010. AMS radiocarbon dating and scientific examination of high historical value manuscripts: application to two Chinese manuscripts from Dunhuang. Journal of Cultural Heritage 11(4):398-403.

Sinoto YH, McCoy PC. 1974. Archaeology of Teti'aroa atoll, Society Islands. Honolulu: Bernice P Bishop Museum. Report 74-2.

Vérin P. 1962. Prospection archéologique préliminaire de Tetiaroa. Société des Etudes Océaniennes 140 XII(3): 103-24. 